\title{
GEOGRAFSKO RAZISKOVANJE TURIZMA IN REKREACIJE V SLOVENIJI
}

\section{Dejan Cigale, Barbara Lampič, Irma Potočnik Slavič, Blaž Repe (ur.): Geografsko raziskovanje turizma in rekreacije $v$ Sloveniji. Zbirka Geo- graFF I5. Znanstvena založba Filozofske fakulte- te Univerze v Ljubljani in Oddelek za geografijo, 228 str. Ljubljana, 2014}

V letu 2014 je zbirko znanstvenih monografij GeograFF obogatila monografija z naslovom Geografsko raziskovanje turizma in rekreacije $v$ Sloveniji. Knjigo sestavlja osem prispevkov, ki se nanašajo na različne razsežnosti geografskega pogleda na turizem in rekreacijo v Sloveniji. Zadnja dva prispevka sta neposredno povezana z ustvarjanjem prof. dr. Matjaža Jeršiča na področju geografije turizma in rekreacije, saj je Oddelek za geografijo z monografijo želel izpostaviti pionirsko vlogo profesorja Jeršiča na področju geografskega preučevanja turizma in rekreacije v Sloveniji tako na znanstvenem kot tudi (planerskem) strokovnem področju ter tako obeležiti njegovo osemdesetletnico.

V prvem prispevku (Značilnosti in težnje razvoja turizma v Sloveniji) Dejan Cigale in Anton Gosar opredeljujeta značilnosti in težnje razvoja turizma v Sloveniji. V obsežni analizi najnovejših podatkov in teženj v razvoju turizma geografsko vrednotita pogoje za razvoj turizma in turizem kot gospodarsko dejavnost v Sloveniji. V nadaljevanju na osnovi dostopnih statističnih in drugih podatkov analizirata turistično ponudbo, turistično povpraševanje in motive tujih turistov za obisk Slovenije. Na koncu analize izpostavljata regionalne razlike $\mathrm{v}$ potencialih za razvoj turizma in rekreacije ter temeljne težnje v slovenskem turizmu.

V nadaljevanju Uroš Horvat (Razvoj turizma v zdraviliških turističnih krajih v Sloveniji), Dejan Cigale, Barbara Lampič in Irma Potočnik Slavič (Geografske značilnosti turizma na kmetiji) ter Simon Kerma (Geografski prispevek k raziskovanju vinskega turizma) podrobneje analizirajo tri specifične oblike turizma: zdraviliški turizem (ki ima že dolgo tradicijo na slovenskem ozemlju), turizem na kmetiji in novejšo tržno nišo, ki se nanaša na pojav vinskega turizma.

Dejan Cigale, Martina Herič, Sandra Kavčič in Miha Varga (Značilnosti potovalnega ravnanja mlajših slovenskih turistov) analizirajo značilnosti potovalnega ravnanja mlajših slovenskih turistov. S pomočjo analize rezultatov anketiranja avtorji opisujejo temeljne značilnosti turističnega ravnanja mlajših, a zelo aktivnih turistov. Miha Koderman (Počitniška bivališča v občini Piran) analizira razvoj, regionalno poreklo lastnikov in prostorske značilnosti počitniških bivališč v najbolj turistični slovenski občini.

Prvi vsebinski sklop sklepata Irena Mrak (Ocena ranljivosti visokogorja kot osnova sonaravnemu razvoju turizma in rekreacije) in Andrej Černe (Zasnova uporabe prostora 
- koncept primernosti (s posebnim ozirom na rekreacijo). Irena Mrak izpostavlja ranljivost visokogorske pokrajine z vidika turizma in rekreacije na primeru Doline Triglavskih jezer in Kriških podov, s čimer opozarja na potrebo po ustreznem vrednotenju geografskih značilnosti ranljivih (zavarovanih) območij za potrebe načrtovanja turizma in rekreacije. Planerske vidike skozi koncept primernosti za razvoj turizma in rekreacije v svojem članku analizira tudi Andrej Černe. Koncept primernosti je bil razvit v sedemdesetih letih 20. st., v času oblikovanja strokovnih podlag za regionalni prostorski plan. Primernost prostora za rekreacijo na prostem je bil prav avtorski prispevek prof. Jeršiča.

Drugi del monografije je posvečen vlogi prof. dr. Matjaža Jeršiča pri razvoju slovenske geografije turizma in rekreacije. Dejan Cigale (Prispevek prof. dr. Matjaža Jeršiča $k$ razvoju slovenske geografije turizma in rekreacije) analizira pogosto pionirski prispevek prof. Jeršiča na področju raziskovanja bližnje rekreacije, turizma v alpskem svetu in sekundarnih počitniških bivališč. Avtor ugotavlja, da Jeršičevo delo predstavlja ključni prispevek h geografskemu raziskovanju turizma in rekreacije v Sloveniji, pri čemer se prof. Jeršič ni osredotočal samo na gospodarski vidik obeh dejavnosti, ampak je ugotavljal tudi njune prostorske vidike ter njun pomen za kakovost življenja. Vsebinski sklop zaokrožuje Bibliografija prof. dr. Matjaža Jeršiča, ki jo je pripravila Ida Knez Račič.

Monografija Geografsko raziskovanje turizma in rekreacije $v$ Sloveniji prinaša analizo in geografsko vrednotenje najnovejših podatkov s področja turizma, rekreacije in preživljanja prostega časa. Pri njenem ustvarjanju so sodelovali geografi različnih generacij, ki nadaljujejo delo prof. Jeršiča tako z geografskimi analizami turizma in rekreacije kot tudi z novejšimi pristopi in temami. Zaradi sodobnega, preglednega, a kompleksnega značaja in problemskega pristopa je GeograFF 15 dragocen znanstveni prispevek na področju geografije turizma in rekreacije v Sloveniji ter zato obvezna literatura za vse, ki se pri delu srečujejo z geografskim pogledom na turizem in rekreacijo, posebej pa še za študente geografije ter različnih smeri študija s področja turizma, prostorskega načrtovanja in ekonomije.

Simon Kušar 